\title{
An Early Proterozoic U-Pb zircon age from an Eskolabreen Formation gneiss in southern $\mathrm{Ny}$ Friesland, Spitsbergen
}

\author{
YU. A. BALASHOV, A. N. LARIONOV, L. F, GANNIBAL, A. N. SIROTKIN, A. M. TEBENKOV. G. I.
} RYÜNGENEN and Y. OHTA

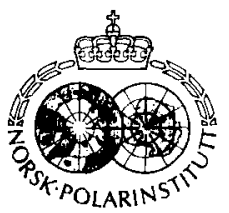

Balashov, Yu. A., Larionov, A. N., Gannibal, L. F., Sirotkin, A. N., Tebenkov, A. M., Ryüngenen, G. I. \& Ohta, Y. 1993: An Early Proterozoic U-Pb zircon age from an Eskolabreen Formation gneiss in southern Ny Friesland, Spitsbergen. Polar Research 12(2), 147-152.

A preliminary $\mathrm{U} / \mathrm{Pb}$ zircon age determination has been carried out on a grey gneiss of the Eskolabreen Formation, the lowest observable lithostratigraphic unit of Precambrian metamorphic rocks in southern Ny Friesland, NE Spitsbergen. The obtained age, ca. 2,400 Ma, is considered to be a metamorphic age and suggests an Early Proterozoic tectonothermal event.

Yu. A. Balashov, A. N. Larionov, L. F. Gannibal, and G. I. Ryüngenen, Laboratory of lsolope Geochemistry, Geological Institute, Kola Science Centre, Russian Academy of Sciences, 14 Fersman Str., 184200 Apatity, Russia; A. M. Tebenkov and A. N. Sirotkin, Polar Marine Geological Exploration Expedition, 24 Pobeda Str., 189510 Lomonosov-St. Petersburg, Russia; Y. Ohta, Norsk Polarinstitutt, P.O. Box 5072 Majorstua, N-0301 Oslo, Norway.

\section{Introduction}

Recent geochronological works on the pre-Calcdonian basement of Svalbard have revealed not only a late Middle Proterozoic tectonothermal event, the Grenvillian (Peucat et al. 1989; Tebenkov et al. 1991; Balashov et al. 1992: Gec et al. in press), but also a latc Early Proterozoic event (Gee et al. 1992; Gavrilenko \& Kamensky 1992) and some Early Proterozoic and older U-Pb zircon upper intercept ages (Peucat et al. 1989: Balashov et al, 1992) and Sm-Nd model ages (Bernard-Griffiths et al. 1993).

Since the Ny Friesland area, northeastern Spitsbergen, has complex structures (Manby 1990; Gec et al. 1992) and the Jargest distribution of the pre-Devonian crystalline basement. Early Proterozoic rocks can naturally be expected. This note reports an Early Proterozoic $\mathrm{U}-\mathrm{Pb}$ zircon age obtained from a gneiss of the Eskolabreen Formation. the lowest lithostratigraphic division of the basement rock succession as defined by Harland et al. (1966).

\section{Geological setting}

Ny Friesland occupies the middle part of the basement areas of northern Svalbard (Fig. 1). The structure in the southern part of Ny Friesland is dominated by an asymmetric antiform, the Atomfjella antiform (Harland 1959). The axis plunges gently to the north. The western limb of the antiform is cut by a steep fault zone, dipping $50-80^{\circ}$ to the west, which is a part of the N-S trending Billefjorden Fault Zone (Harland et al. 1974), the latter down throws to the west. Some Carboniferous cover has been preserved on the basement block in the east side of Austfjorden. The eastern limb of the antiform is cut by a steep E dipping, partly thrust, fault within the antiform and the Finlandveggen Group is in contact with the Harkerbreen Group (Table 1) by this fault. Along the eastern margin of the antiform the Harkerbreen Group is in contact with the Mossel series (Krasil'šikov 1973) or the Planetfjella Group of the upper Stubendorffbreen Supergroup (Harland et al. 1966) by a Wdipping thrust fault.

The core of the antiform is composed of the Smutsbreen and the Eskolabreen Formations of the Finlandveggen Group (Harland et al. 1966; Krasil'ščikov 1973; Harland 1985, 1992). The Smutsbreen Formation consists of grey biotite gneisses with or without garnet and distinctive marble layers. The latter are in both the lower and upper parts, and small amounts of caicsilicate-gneisses and amphibolites also present. The Eskolabreen Formation is the lowest observable lithostratigraphic unit and is composed of garnet-hornblende-biotite- and hornblende-biotite gneisses, amphibolites and granitic gneisses. These rocks have upper amphibolite facies mineral assemblages of high temperature series with andalusite-sillimanite, while the rocks of this formation in the limbs have kyanite-garnet-mica assemblages without sillimanite, indicating a lower temperature condition than in the core and an intermediate temperaturepressure series.

The Flåtan granite in the northern part of Ny Friesland (Fig. 1) has a $1,788+53 / .45 \mathrm{Ma} \mathrm{U}-\mathrm{Pb}$ zircon isochron age. It also 


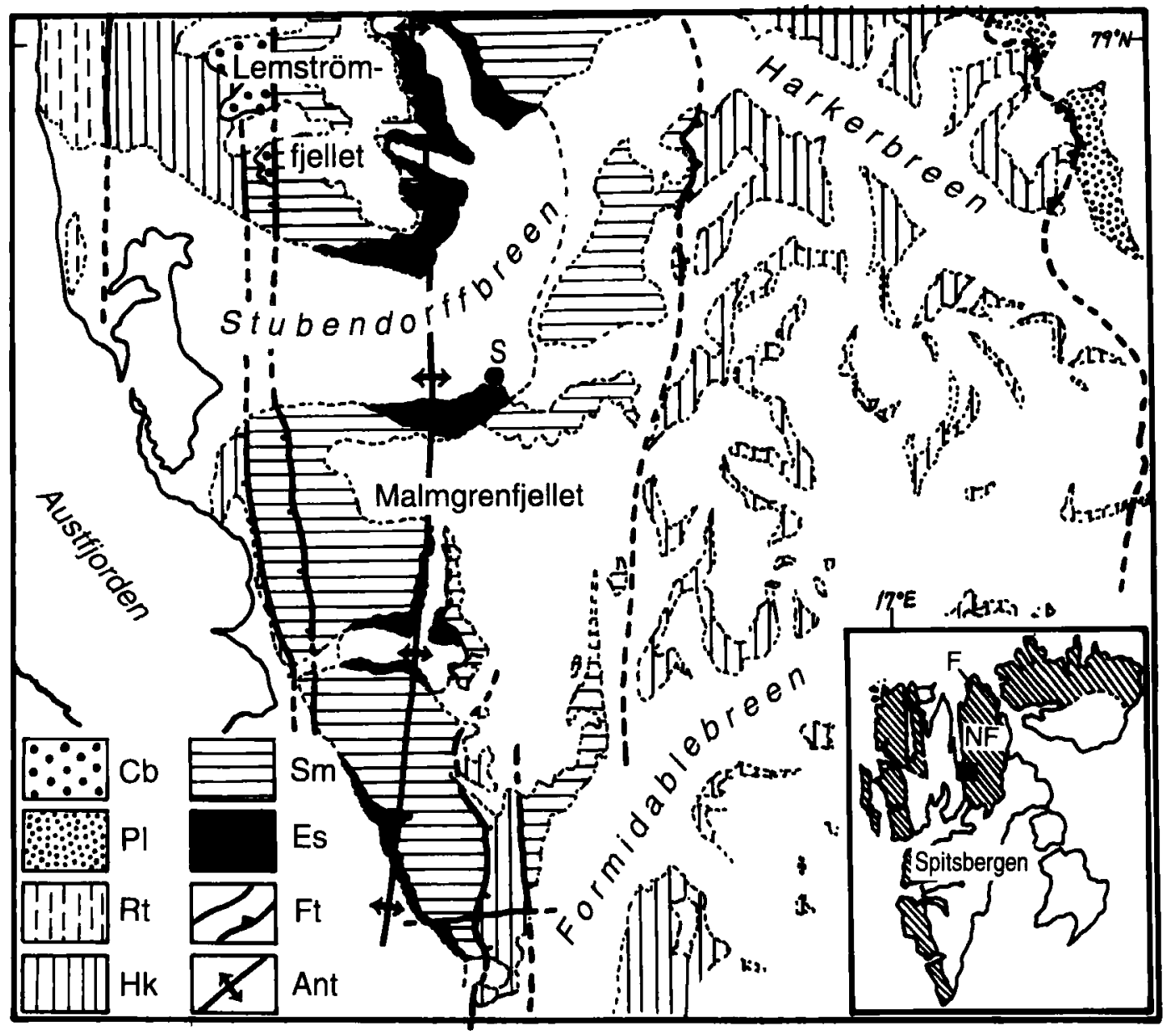

Fig. I. Generalized geological map of southern Ny Friesland, with the sample locality. Inserted map: Solid square = map area, dashed area $=$ pre-Devonian basement, $\mathrm{NF}=\mathrm{Ny}$ Friesland, $\mathrm{F}=$ Flătan granite. Legend: $\mathrm{Cb}=$ Carboniferous, $\mathrm{PI}=\mathrm{Planetfjella}$ Group or Mossel series, Rt $=$ Rittervatnet Formation, $\mathrm{Hk}=$ Polhem or Harkerbreen Formation, $\mathrm{Sm}=$ Smutsbreen Formation, $\mathrm{Es}=$ Eskolabreen Formation, $\mathrm{Ft}=$ fault and thrust, $\mathrm{Ant}=$ Atomfjella antiform. $\mathrm{S}$ with a solid circle $=$ sample locality.

yiclded zircon single grain ages of ca. 1,700 Ma (Gee et al. 1992). This granite possibly intruded in the gneisses and amphibolites of the Polhem Formation in the lower part of the Harkerbreen Group (Table 1). Thus the protoliths of the gneisses and amphibolites are of Early Proterozoic. Ultramafic rocks separating the Polhem Formation from the Planetfjella Group have yielded a ca. $1.8 \mathrm{Ga}$ age and a biotite concentrated rock adjacent to them gives an age of $500 \mathrm{Ma}$, both by the K-AI method (Gavrilenko \& Kamensky 1992), though the reliability of these $\mathrm{K}$-Ar data is a matter of debate.

This note presents a preliminary U-Pb zircon age obtained from an Eskolabreen Formation gneiss in southern Ny Friesland. This age was orally presented by Balashov in August 1993 at Turku, Finland.

\section{Materials and methods}

\section{Sample description}

A grey gneiss (ca. $30 \mathrm{~kg}$ ) from the Eskolabreen Formation in the middle-southern side of Stubendorffbreen has been used for this isotopic study. The locality is shown in Fig. 1. The rock is a coarse-grained, feldspar porphyroblastic, gamet-hornblendebiotite gneiss with a modal composition of $25-30 \%$ quartz, 25$30 \%$ plagioclase $\left(\mathrm{An}_{20-25}\right), 30-40 \% \mathrm{~K}$-feldspar, $10 \%$ biotite, 1$2 \%$ hornblende and $1-2 \%$ garnet with accessories of apatite, zircon, monazite and opaques; the secondary minerals are chlorite, sericite and epidote.

This gneiss forms persistent layers, up to $5 \mathrm{~m}$ in each thick- 

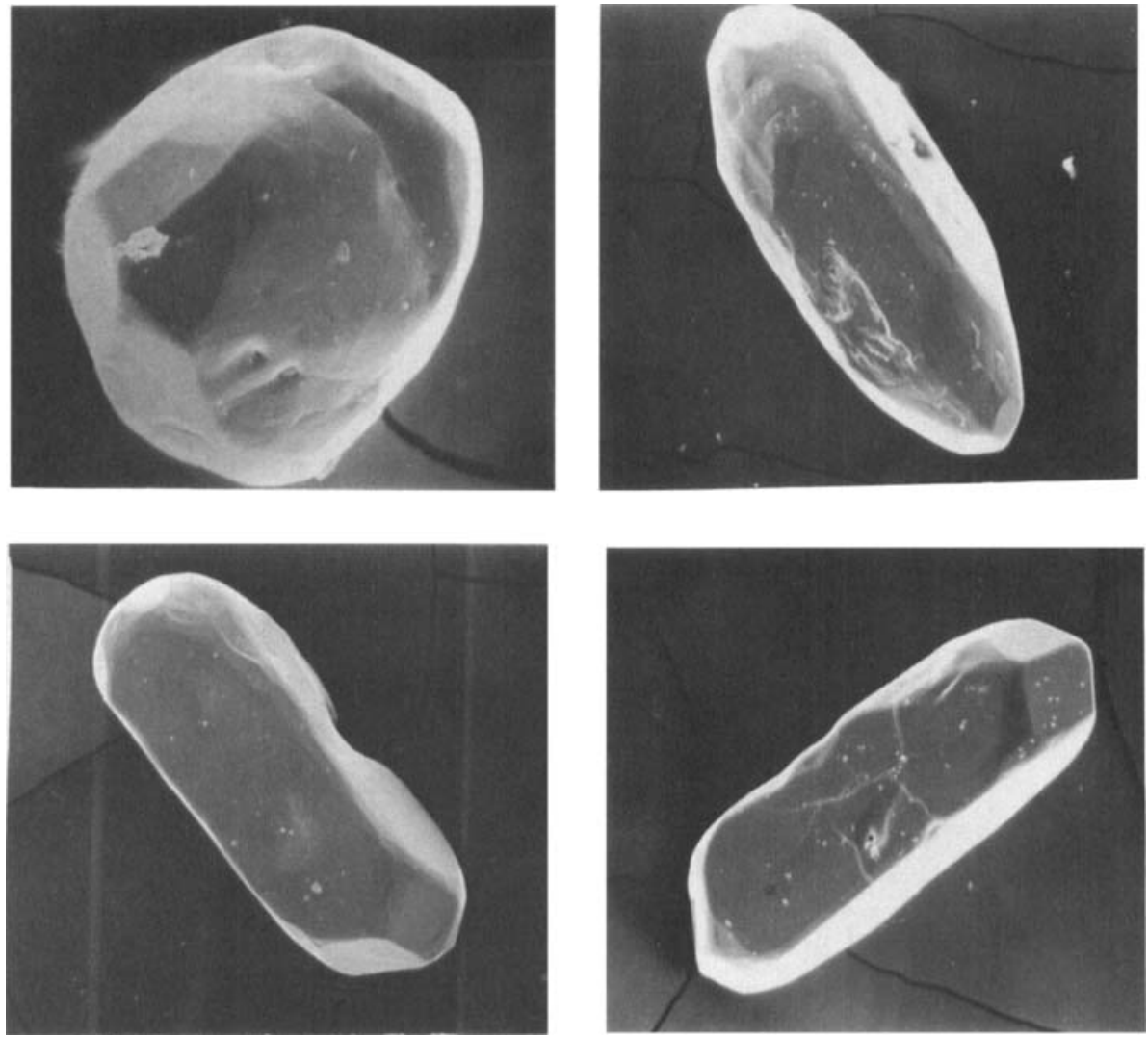

Fig. 2. Morphotypes of the zircon grains, scanning electro-micrographs. Upper left, morphotype $1, \times 480$, upper right, morphotype $1 \times 168$; lower left and lower right morphotype 2 , both $\times 240$.

Table 1. Lithostratigraphic schemes of Middle and Early Proterozoic successions in Ny Friesland, after Harland et al. (1985) and Krasil'šcikov (1973).

\begin{tabular}{|c|c|c|c|c|}
\hline \multicolumn{3}{|c|}{ Harland et al. 1966} & \multicolumn{2}{|c|}{ Krasilscikov 1973} \\
\hline Planetfjellet Grou & & $\stackrel{\mathscr{O}}{\Xi}$ & Mossel series & \\
\hline $\begin{array}{l}\text { Sørbreen Fm. } \\
\text { Vassfaret Fm. } \\
\text { Bangenhuk Fm. } \\
\text { Rittervatnet Fm. } \\
\text { Polhem Fm. }\end{array}$ & 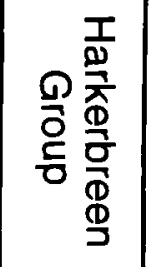 & 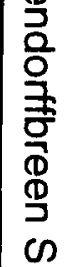 & $\begin{array}{l}\text { Sørbreen Fm } \\
\text { Vassfaret Fm. } \\
\text { Bangenhuk Fm. } \\
\text { Rittervatnet Fm. } \\
\text { Harkerbreen Fm. }\end{array}$ & $\frac{\stackrel{2}{\overrightarrow{0}}}{\frac{3}{3}}$ \\
\hline $\begin{array}{l}\text { Smutsbreen Fm. } \\
\text { Eskolabreen Fm. }\end{array}$ & 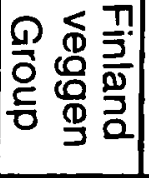 & $\begin{array}{l}\bar{D} \\
\text { D } \\
\text { 음 } \\
\text { 듬 }\end{array}$ & $\begin{array}{l}\text { Smutsbreen Fm. } \\
\text { Eskolabreen Fm. }\end{array}$ & 离. \\
\hline
\end{tabular}




\begin{tabular}{|c|c|c|c|c|c|c|c|}
\hline \multirow{4}{*}{ 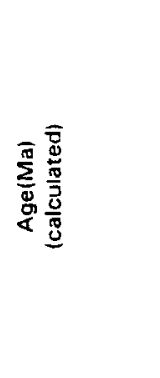 } & 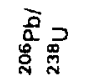 & $\stackrel{\mathscr{m}}{\Xi}$ & 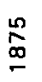 & $\stackrel{\infty}{g}$ & ¿্ & $\begin{array}{l}\text { o } \\
\text { m }\end{array}$ & 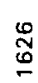 \\
\hline & 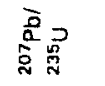 & $\stackrel{\frac{7}{5}}{\check{L}}$ & 总 & $\frac{⿱}{n}$ & $\stackrel{0}{\stackrel{2}{N}}$ & $\begin{array}{l}\stackrel{8}{\circ} \\
\vdots\end{array}$ & $\begin{array}{l}20 \\
2 \\
2\end{array}$ \\
\hline & 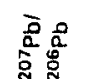 & $\frac{\tilde{q}}{\tilde{V}}$ & $\underset{\widetilde{N}}{\tilde{N}}$ & 怘 & 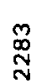 & ठิ & $\stackrel{ \pm}{\stackrel{\Xi}{\pi}}$ \\
\hline & 옫 & $\begin{array}{c}\hat{D} \\
\infty \\
0 \\
0\end{array}$ & g్d & $\frac{\sigma}{\infty}$ & : : & 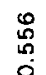 & $\begin{array}{l}\infty \\
\infty \\
\infty \\
0\end{array}$ \\
\hline \multirow{8}{*}{ 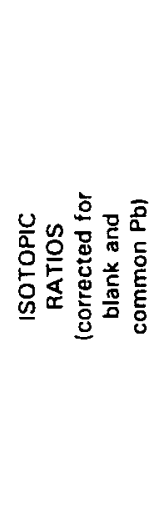 } & $\therefore$ & ָָ̃ & חָ & 品 & i্ণ & ֻొ & 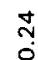 \\
\hline & 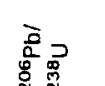 & 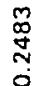 & 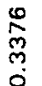 & $\begin{array}{c}\text { 幽 } \\
\text { ch } \\
0 \\
0\end{array}$ & 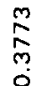 & ্ֻণ্ণী & 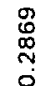 \\
\hline & & $\bar{m}$ & $\stackrel{\circ}{2}$ & $\hat{m}$ & $q$ & ஃ & $\stackrel{\infty}{\sim}$ \\
\hline & $\sigma_{\bar{\omega}}$ & $\circ$ & $\circ$ & $0^{\circ}$ & $\circ$ & $\circ$ & $0^{\circ}$ \\
\hline & 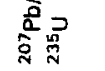 & 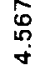 & . & 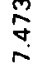 & 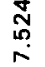 & $\underset{\substack{\tilde{N} \\
\text { ja }}}{ }$ & 象 \\
\hline & 20 & $\frac{\sigma}{0}$ & $\begin{array}{c}\overline{1} \\
0\end{array}$ & $\underset{0}{\overline{0}}$ & 용 & ळ్ & $\frac{m}{8}$ \\
\hline & 30 & 芯 & ఖ্ণ & g্ & \& & $\stackrel{\text { న̊ }}{\alpha}$ & 品 \\
\hline & 品 & $\overline{0}$ & $\dot{\circ}$ & $\overline{0}$ & $\overline{0}^{\circ}$ & $\overline{0}$ & $\overline{0}$ \\
\hline \multirow{8}{*}{ 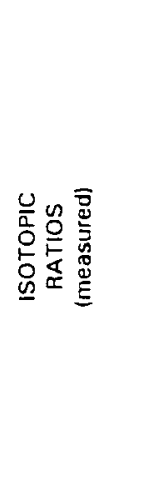 } & $x^{\circ}=$ & $\stackrel{ \pm}{i}$ & 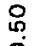 & in & $\stackrel{0}{0}$ & $\frac{Z}{4}$ & ตु. \\
\hline & a & 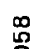 & ชิ & o & 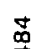 & if & $\infty$ \\
\hline & 总 总 & $\stackrel{?}{i}$ & $\bar{\pi}$ & $\dot{0}$ & ف & 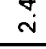 & $\cong$ \\
\hline & $\therefore \bar{\omega}$ & $\frac{0}{0}$ & $\begin{array}{l}? \\
0 \\
0\end{array}$ & શి & 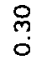 & సָ & $\begin{array}{l}\text { o } \\
0 \\
0\end{array}$ \\
\hline & a & $\stackrel{D}{D}$ & 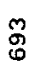 & ్ֶ & $\underset{\infty}{\mathbb{\infty}}$ & $\stackrel{\oplus}{\sim}$ & 孞 \\
\hline & 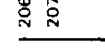 & $\because$ & $\ddot{0}$ & 0 & $\omega$ & $\dot{\sigma}$ & \\
\hline & $\therefore$ & $\stackrel{0}{\dot{\sigma}}$ & $\hat{i}$ & 㐫 & $\stackrel{\circ}{=}$ & o & m \\
\hline & 高兘 & : & : & $\frac{\infty}{m}$ & 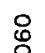 & $\overline{\bar{\gamma}}$ & $\stackrel{5}{3}$ \\
\hline \multirow{5}{*}{$\frac{a}{a}$} & 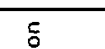 & & $\overline{5}$ & & & & \\
\hline & 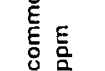 & 声 & $\begin{array}{l}\text { O. } \\
\dot{0} \\
v\end{array}$ & $\stackrel{\mathscr{m}}{\stackrel{\Xi}{\circ}}$ & 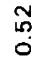 & $\begin{array}{l}\stackrel{8}{8} \\
\stackrel{\rho}{0} \\
0\end{array}$ & $\tilde{o}$ \\
\hline & 음 & 品 & $\hat{0}$ & $\stackrel{m}{m}$ & 它 & f & 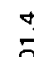 \\
\hline & 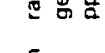 & & & & & & \\
\hline & 돔 & 号 & $\stackrel{\Xi}{\square}$ & 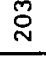 & $\stackrel{\circ}{\circ}$ & 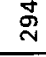 & $\hat{m}$ \\
\hline & 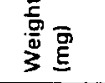 & $\stackrel{\infty}{0}$ & $\cong$ & $\stackrel{0}{\circ}$ & $\stackrel{0}{\infty}$ & $\stackrel{9}{\circ}$ & 0 \\
\hline & 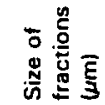 & $\begin{array}{l}\text { مُ } \\
\text { م⿱⺈ }\end{array}$ & $\frac{8}{5}$ & $\frac{8}{1}$ & $\frac{8}{1}$ & $\begin{array}{l}\text { 㗐 } \\
\text { V }\end{array}$ & $\frac{8}{8}$ \\
\hline & g̊ ำ & - & N & $m$ & $\sigma$ & مص & c \\
\hline
\end{tabular}


ness, altcrnating with pink granitic gncisses and thin amphibolites of hornblende-biotite gneisses and is located about $100 \mathrm{~m}$ below the upper boundary of the Eskolabreen Formation in the core of the Atomfjella antiform. Many isoclinal fold hinges occur within layers and the gneissosities are all of tectonicmetamorphic in origin.

\section{Zircons}

Two morphotypes of zircon grains are distinguished in the rock (Fig. 2):

(1) Grains with facets of (111), (311), (110). (100) and wide bulging margins between them, having apparent oval or rounded outlines with the width/length ratios 1.5-2.5. They have smooth surfaces and are commonly transparent, yellow to brownish in colour. Some grains have thin overgrowths at the pinacles.

(2) Prismatic grains with (111) and (100) facets. These have relatively rough surfaces and the width/length ratios are 2-3.5. The colours are similar to morphotype 1 , but darker and not as clear due to the rougher surfaces.

Zircons of both morphotypes have some inclusions of brown needles, probably thorite, and glass-liquid bubbles. The surfaces of grains do not show any abrasion pattern as usually seen on the surfaces of detrital grains. Thermal-ion mass-spectrometry studies on both types of zircon grains show a large difference in ${ }^{207} \mathrm{~Pb} /{ }^{206} \mathrm{~Pb}$ age (ca. 2.36 and $1.87 \mathrm{Ga}$ ), indicating at least two generations of the grains. The zircons of morphotype 2 have not been analysed in this preliminary study because they are considered to have a complex history of crystallization and would therefore give results difficult to interpretate.

Six size fractions of morphotype 1 zircon grains have been chosen for the present $\mathrm{U} / \mathrm{Pb}$ analyses. Only transparent grains without overgrowth at the pinacles have been selected. Fraction 4 was air-abraded to remove the inner part and fraction 6 was additionally milled.

\section{Isotope analyses and results}

Extraction of $\mathrm{U}$ and $\mathrm{Pb}$ was performed by Krogh's (1973) method. After being washed with diluted nitric acid, the zircon grains were dissolved in $2 \mathrm{ml} \mathrm{HF}$ in teffon capsules and heated in aluminium bombs in an oven at $185^{\circ} \mathrm{C}$ for some days. After dissolution and aliquotation, the ID part was spiked with a mixed 235U-208Pb tracer. $\mathrm{U}$ and $\mathrm{Pb}$ were separated by ionexchange using $6.2 \mathrm{M} \mathrm{HCl}$ and water. Total blank during the

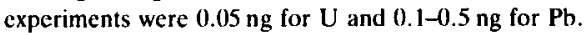

The samplc was loaded with nitric acid on a double Re filament for $\mathrm{U}$ and with silica gel and phosphoric acid on a single Re filament for $\mathrm{Pb}$. Both were analysed with a MI1201-T single collector mass spectrometer. The results of the measurements were corrected for blanks of $0.5 \mathrm{ng}$ for $\mathrm{Pb}$ and $0.05 \mathrm{ng}$ of $\mathrm{U}$, and common lead using Stacey \& Kramer's model (1975) for an age of $2.450 \mathrm{Ma}$.

The results of $\mathrm{U}$ and $\mathrm{Pb}$ isotope analyses are given in Table 2 and the obtained isochron is illustrated in Fig. 3. The four fractions define a discordia with an upper intercept of $2,415+-34 \mathrm{Ma}$ and a lower intercept of $624+-68 \mathrm{Ma}$, with MSWD $=6.9$. Two fractions, 4 and 6 , are off from the discordia, probably due to later thermal effects and/or contamination during the air-abrasion for fraction 4.

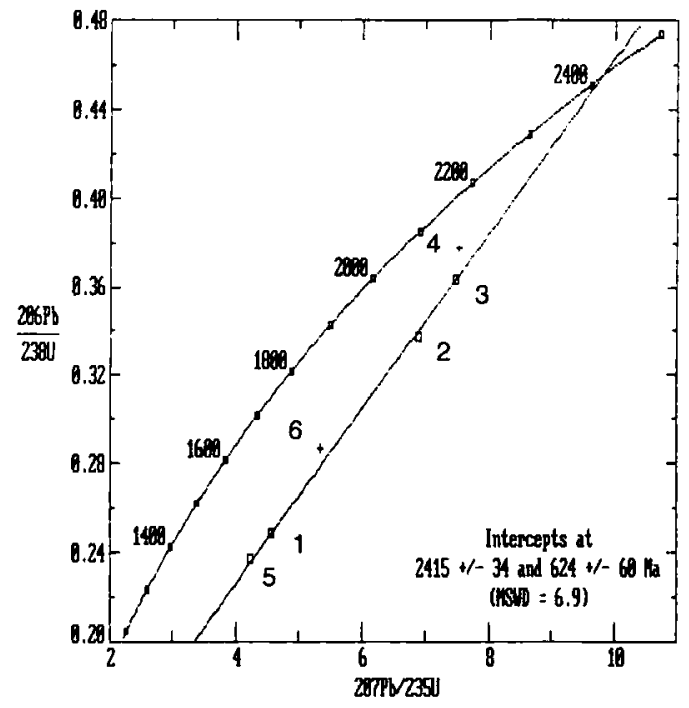

Fig. 3. U.Pb concordia diagram. Number of sample refers to Table 2 .

\section{Discussion}

Close structural observations of the Stubendorffbreen Supergroup in this area show that all layered and banded structures in the rocks are of tectonic origin; no stratigraphic (sensu stricto) definition is therefore possible and the successions must be defined as lithostratigraphic of tectonostratigraphic units (Manby 1990; Gee et al. in press).

The protoliths of the rocks of the Harkerbreen and Finlandveggen Groups have been considered to be areno-argillaccous and arkosic sediments and bi-modal igneous rocks of mostly eruptive origin. The volcanigenic origin of some of these rocks has also been discussed by Manhy (1990) and Sirotkin (unpubl. report). The latter author suggested a difference in a sedimentary environment for these groups, an extensional deep sea basin for the Finlandveggen Group and a transgressional shallow sea - subaerial basin for the Harkerbreen Group.

All previous authors agreed that these two groups belong to a large volcani-sedimentary succession without any orogenic break within it, though all observed contacts between the two groups are cut by thrust or steep fault in southern Ny Friesland.

The obtained U-Pb upper intercept age can be considered as a metamorphic zircon age, judging from the transparent colour, smooth surfaces lacking any trace of abrasion and the absence of any clearly zoned structure. This age is applicable to both the Eskolabreen and the Smutsbreen Formations, since these are conformable both in structure and metamorphism, but this age is not applicable to the Harkerbreen Group since this group is scparated by faults from the Smutsbreen Formation in this area. This U-Pb upper intercept age suggests an older tectonothermal event than the emplacement of the Flåtan granite at ca. $1.7 \mathrm{Ga}$ (Gee et al. 1992) in Ny Friesland. Similar ages of ca. $2.4-2.5 \mathrm{Ga}$ have also been obtained recently from U-Pb upper intercepts of zircon from a quartz porphyryrhyolite clasts in a conglomerate-pyroclastic unit of the northwestern Hornsund (Balashov et al. 1992). 
The Caledonian and Precambrian rocks of Ny Friesland have becn compared with those of East Greenland (Harland 1985; Gee et al. 1992). There the 4-10 km thick Krummedal supracrustal sequence (Higgins 1988) has been metamorphosed during the Grenvillian period (e.g, Peucat et al. 1985), while much older U-Pb zircon upper intercept ages, ca. 1.9-3.0 Ga (Hansen \& Friderichsen 1987; Hansen et al. 1987) and ca. $2.5 \mathrm{Ma}$ (Peucat et al. 1985) have also been reported. However. these rocks are involved in complex gneiss-migmatite structures and the discrimination between Middle and Early Proterozoic rocks has not yet been completed.

The palinspastic position of Svalbard before Cenozoic ocean spreading is not too far from northern Ellesmere Island, and a structural unit of Caledonian affinity, Pcarya, has been recognized in that area (Trettin 1987). Recent U-Pb zircon studies on the Caledonian and older rocks in Pearya yielded older ages than the Grenvillian, ca. 2.1 and ca. $2.2 \mathrm{Ga}$ (Trettin et al. 1992). Both are considered to be from inherited zircons, but no geological constraints are known yet.

No correlative geological event has ever been observed in the present area which corresponds with the lower intercept age, ca. $625 \mathrm{Ma}$. But a few similar $\mathrm{Rb}-\mathrm{Sr}$ and $\mathrm{K}-\mathrm{Ar}$ ages are known in the northern parts of Nordaustlandet (Hamilton \& Sandford 1964; Ohta 1992). A similar age for eclogitic metagabbroic rock has been obtained from Biskayerhalvøya (Peucat ct al. 1989). This period corresponds to the time of the Baikalian event in the southeastern Barents Sea region; however, all these ages in Svalbard are from igneous rocks and no distinguishing structural event of this period has yet been recognized.

Acknowledgements. - The authors are grateful for critical comments to the manuscript given by D. G. Gee, University of Lund. Sweden, and $\AA$. Johansson, Swedish Museum of Natural History, Stockholm. We would also like to thank A. A. Krasil'sccikov, Polar Marine Geological Expedition, Lomonosov, Russia, for organizing of the project.

\section{References}

Balashov, Yu. A., Fedotov, J. A., Skufjin, P. K., Sharkov, I. V., Kravchenko, M. P., Sherstobitova, G. M. \& Ulianenko, N. A. 1992: Evoljucia vulcanizma v pechengskoy osadochnovulkanogennoy tolsche po Rb-Sr izotoponym dannym. Tezisy XIII Simposiuma geochimii isotopov. Moskwa, GEOCHI, Rossijskaja Academija Nauk. Pp. 16-17 (in Russian).

Bernard-Griffiths, J., Peucat, J. J. \& Ohta, Y. 1993: Age and nature of protoliths in a Caledonian blueschist-eclogite complex of western Spitsbergen: a combined approach of $U$ $\mathrm{Pb}, \mathrm{Sm}-\mathrm{Nd}$ and REE whole rock systems. Lithos 30, 81-90.

Bojanova, T. B. \& Jacovenchuk, V. N. 1992: U-Pb datirovanie baddeleita i zirkona granofirovyh porod Imandra-Varzugskoy struktury. Doklady Rossijskoj Academi i Nauk 322, 138-141 (in Russian).

Gavrilenko, B. V. \& Kamensky, I. L., 1992: K-Ar isochronnyi vozrast $\mathrm{i}$ isotopy kalija $\mathrm{v}$ hyperbasitovoj dake na poluostrove Mossel, Ny Friesland, Spitsbergen. Geochimija 2, 124-129 (in Russian).

Gee, D. G., Björklund, L. \& Stølen, L-K. (in press): Early Proterozoic basement in Ny Friesland.-Implications for the Caledonian tectonics of Svalbard. Tectonophysics.

Gec, D. G., Schouenborg, B., Peucat, J. J., Abakumov, S. A., Krasil'šcikov, A. A. \& Tebenkov, A. M. 1992: New evidence of basement in the Svalbard Caledonides: Early Proterozoic zircon ages from Ny Friesland granites. Norsk Geol. Tidsskr. $72,181-190$.

Hamilton, E. I. \& Sandford, K. S. 1964: Rubidium-Strontium ages from North-East Land (Spitsbergen). Nature 201, 12081209.

Hansen, B. T. \& Friederichsen, J. D. 1987: Isotopic agc dating in Liverpool Land, East Greenland. Gron. Geol. Undersøgelse Rapp. 134, 25-37.

Hansen, B. T., Steiger, R. H., Henriksen, N. \& Borchardt, B. 1987: U-Pb and $\mathrm{Rb}-\mathrm{Sr}$ age determinations on Caledonian plutonic rocks in the central part of the Scoresty Sund region, East Greenland. Grøn. Geol. Undersøgelse Rapp. 134, 5-24.

Harland, W. B. 1959: The Caledonian sequence in Ny Friesland, Spitsbergen. Q. J. Geol. Soc. London 114, 307-342.

Harland, W. B. 1985: Caledonide Svalvard. Pp. 999-1011 in Gee, D. G. \& Sturt, B. (eds.): The Caledinide orogeny Scandinavia and related areas, Part 2, John Wiley \& Sons. Chichester.

Harland, W. B. 1992: The Ny Friesland Orogen, Spitsbergen. Geol. Mag. 129, 679-708.

Harland, W. B., Wallis, R. H. \& Gayer, R. A. 1966: A revision of the Lower Hecla Hoek Succession in central north Spitsbergen and correlation elsewhere. Geol. Mag. 103, 701-97.

Harland, W. B., Cutbill, J. L., Friend, P. F., Cobbett. D. J., Holiday, D. W., Maton, P. I., Parker, J. R. \& Wallis, R. H. 1974: The Billdfjorden Fault Zone, Spitsbergen. Norsk Polarinst. Skr. 161. $72 \mathrm{pp}$.

Higgins, A. K. 1988: The Krummedal supracrustal sequence in East Greenland, Pp. 86-96 in Winchester, J. A. (ed.); Late Proterozoic stratigraphy of the northern Atlantic region. Blackie, Glasgow.

Krasil'scikov, A. A. 1973: Stratigrafija i paleotectonica Docambrijurannego Palcozoya Spitsbergen. Trudy Instituta Geologii Arktiki 172, 1-119 (in Russian).

Krogh, T. E. 1973: A low-contamination method for hydrothermal dissolution of zircons and extraction of $U$ and $\mathrm{Pb}$ for isotopic age determinations. Geochemica et Cosmochemica Acta 37, 485-494.

Manby, G. M. 1990: The petrology of the Harkerbreen Group. Ny Friesland, Svalbard: protoliths and tectonic significance. Geol. Mag. 127, 129-146.

Ohta, Y. 1992: Recent understanding of the Svalbard basement in the light of new radiometric age determinations. Norsk Geologisk Tidskrift 72, 1-6.

Peucat, J. J., Tisserant, D., Caby, R. \& Clauer, N. 1985: Resistance of zircons to resetting in a prograde metamorphic sequence of Caledonian age, East Greenland. Can.J. Earth Sci. 22, 330-338.

Peucat, J. J.. Ohta, Y. \& Gee, D. G. and Bernard-Griffiths, J. 1989: U-Pb, $\mathrm{Sr}$ and $\mathrm{Nd}$ evidence for Grenvillian and latest Proterozoic tectonothermal activity in the Spitsbergen Calcdonides, Arctic Ocean. Lithos 22, 275-285.

Staccy, J.S. \& Kramer, J. D. 1975: Approximation of terrestrial lead isotope evolution by a two-stage model. Earth Planet. Sci. Lett. 26, 207-221.

Tebenkov, A. M. Balashov, Yu. A. \& Krasil'šikov, A. A. 1991; Trace of pre-Paleozoic events in Svalbard Caledonides. Terra Abstract Supplement 4 to Tera Nova 3, p. 32.

Trettin, H. P. 1987: Pearya; a composit terrane with Caledonian affinities in northern Ellesmere Island. Can. J. Earth Sci. 24, 224-245.

Trettin, H. P., Parrish, R. R. \& Ruddick, J. C. 1992: New U$\mathrm{Pb}$ and 40Ar-39Ar age determinations from northern Ellesmere and Axel Heibergh islands, Northwest Territories and their tectonic significance. Radiogenic Age and lsotopic Studies: Report 6, Geol. Survey of Canada, Paper 92-2, 3-30. 